\title{
SINDROM SAGORIJEVANJA MEĐU ZDRAVSTVENIM RADNICIMA U PANDEMIJI BOLESTI COVID-19
}

\author{
STIPE DRMIĆ, LEA MURN*
}

Sindrom sagorijevanja na poslu (engl. burnout syndrome) rezultat je kroničnog stresa na poslu, uz korištenje relativno neučinkovitih strategija suočavanja sa stresom, a mnogobrojne studije provedene na medicinskim sestrama i liječnicima potvrđuju kako su mu posebno izloženi zdravstveni radnici. Tijekom pandemije bolesti COVID-19, zdravstveno osoblje postalo je izloženo i dodatnim stresnim čimbenicima, što povećava mogućnost razvijanja sindroma sagorijevanja. Ovaj pregledni rad donosi najnovije podatke o stopi prevalencije sindroma sagorijevanja u zdravstvenih radnika (medicinskih sestara i liječnika), prije i za vrijeme krize izazvane virusom SARS-CoV-19, te razmatra čimbenike koje utječu na razvitak sindroma sagorijevanja, s ciljem identificiranja čimbenika koji djeluju protektivno na mentalno zdravlje zdravstvenih djelatnika. Prikupljeni podaci u brojnim studijama potvrđuju kako je od velikog značenja pravovremeno razviti strategije prevencije, liječenja i rehabilitacije osoba sa sindromom sagorijevanja, čime bi se održalo mentalno zdravlje medicinskog osoblja, ali i kvaliteta skrbi koja se pruža pacijentima unutar zdravstvenog sustava.

Ključne riječi: SINDROM SAGORIJEVANJA, COVID-19, MEDICINSKE SESTRE, LIJEČNICI

\section{Sindrom sagorijevanja}

Sindrom sagorijevanja (engl. burnout syndrome) prvi put spomenut je 70-tih godina prošlog stoljeća, prilikom proučavanja emotivnog distresa u radnika koji se bave pomagačkim zanimanjima u zdravstvu (1). U tadašnjih radnika primijećena je emocionalna iscrpljenost, negativni stavovi i osjećaji prema klijentima te nesigurnost na području profesionalnih kompetencija. Kreiran je i psihometrijski instrument za dijagnosticiranje poremećaja - engl. Maslach Burnout Inventory (MBI), koji je i dalje zlatni standard za utvrđivanje postojanja poremećaja sagorijevanja $(2,3)$.

Prema trenutno važećim međunarodnim klasifikacijama (MKB-10, Međunarodna klasifikacija bolesti i srodnih zdravstvenih problema, 10. revizija i

\footnotetext{
*KB Dubrava, Klinika za psihijatriju

Adresa za dopisivanje:

Dr. sc. Stipe Drmić, dr. med.

KB Dubrava, Klinika za psihijatriju

10000 Zagreb, Avenija Gojka Šuška 6

E-mail: stipe.drmic@gmail.com
}

DSM-5, Dijagnostički i statistički priručnik za duševne poremećaje (engl. Diagnostic and statistic manual of mental disorders, 5. izdanje), sindrom sagorijevanja se ne opisuje kao zasebna kategorija, već se može koristiti dijagnoza Poremećaj prilagodbe. U 11. reviziji Međunarodne klasifikacije bolesti (MKB-11, koja stupa službeno na snagu 1. siječnja 2022.), sindrom sagorijevanja nije klasificiran kao zdravstveno stanje, nego kao profesionalni fenomen, kojeg karakteriziraju tri dimenzije: 1 . osjećaj iscrpljenosti ili iscrpljenosti energije; 2. povećana mentalna udaljenost od posla ili osjećaj negativizma ili cinizma vezanog za posao (depersonalizacija); 3. smanjena profesionalna učinkovitost. Sindrom sagorijevanja rezultat je kroničnog stresa na poslu, uz korištenje relativno neučinkovitih strategija suočavanja sa stresom (4).

Simptomi sindroma sagorijevanja su i teškoće koncentracije, razdražljivost ili emocionalna nestabilnost, nesanica, bolovi u mišićima, vrtoglavice i palpitacije. Ti simptomi trebaju biti prisutni barem dva tjedna, moraju uzrokovati značajnu patnju sa smanjenom radnom sposobnošću te se ne smiju odnositi na drugu dijagnozu ili zlouporabu psihoaktivnih supstanci (5).

U pomagačkim zanimanjima sindrom sagorijevanja je češći, što se tumači visoko postavljenim ciljevima i idealima u svakodnevnom radu te dnevnim opterećenjem koje nadilazi stvarne kapacitete za suočavanje sa stresom (6).

Istraživanja pokazuju kako su medicinski djelatnici izloženi puno većoj razini stresa na radnom mjestu u odnosu na opću populaciju u normalnim okolnostima, te su izloženi većem riziku od psihosomatskih bolesti (7-9). Ipak, osoba izložena stresu još uvijek koristi razne strategije suočavanja sa stresom, ima volje i motivacije da se bori, ali kad dođe do sindroma sagorijevanja, osoba osjeća veliki gubitak motivacije, nema više želju ići na posao, intenziviraju se psihičke i somatske tegobe te ima osjećaj kao da se više nema snage boriti.

Zdravstveni radnici, medicinske sestre i liječnici pripadaju zanimanjima koja imaju najveće postotke sindroma sagorijevanja, što je dodatno povećano krizom koju je izazvala pandemija bo- 
lesti COVID-19 (10). Tijekom izbijanja SARS-CoV-2 virusa, zdravstveni radnici suočavaju se s povećanim psihološkim pritiskom, što se očituje u većim razinama stresa, anksioznosti i depresije, pa i psihičkim poremećajima $(11,12)$. Burnout u zdravstvenih radnika utječe na osjećaj sreće, odnose, zadovoljstvo karijerom i brigu za pacijente, a nažalost, prema studiji iz 2021. publiciranoj na Medscapeu, povećana stopa sindroma sagorijevanja rezultirala je i povećanom stopom suicida liječnika, što govori o nužnosti otvaranja diskursa na društvenoj razini o sindromu sagorijevanja $u$ zdravstvenih radnika (13).

Pojavnost i rasprostranjenost sindroma sagorijevanja među zdravstvenim radnicima

Epidemiološki podaci o pojavnosti i rasprostranjenosti (tj. incidenciji i prevalenciji) sindroma sagorijevanja govore o visokom postotku zdravstvenih radnika $\mathrm{u}$ burnout sindromu, posebice u krizi zbog pandemije bolesti COVID-19. Limitirajući čimbenici za istraživanja su dijagnostika burnouta preko samoocjenskih upitnika, a često su zdravstveni radnici, koji se odluče na sudjelovanje u istraživanjima o sindromu sagorijevanja, upravo oni koji su mu najizloženiji te je zbog toga njihov udio potencijalno viši (15).

O visokim stopama sindroma sagorijevanja i prije pandemije bolesti COVID-19 govori meta-analiza iz 2018. godine, kojom su obuhvaćena 182 istraživanja objavljena između 1991. i 2018. godine. Prevalencije sindroma sagorijevanja među liječnicima su bile: $67,0 \%(122 / 182)$ za ukupno sagorijevanje, 72,0\% (131/182) za emocionalnu iscrpljenost, $68,1 \%(124 / 182)$ za depersonalizaciju i 63,2\% (115/182) za slabo osobno postignuće (10). Od 2013. godine, Medscape objavljuje rezultate godišnje ankete među liječnicima u Sjedinjenim Američkim Državama koje ispituju učestalost simptoma sindroma sagorijevanja, kao i anksioznosti, depresivnosti i suicidalnosti. Prema izvještajima, stopa burnouta među liječnicima ima trend rasta od 2013. godine, a zdravstveno osoblje koje je i prije krize izazvane pandemijom bilo u velikom postotku zahvaćeno sindromom sagorijevanja, može očekivati značajnije posljedice krize na mentalno zdravlje (14).

\section{Sindrom sagorijevanja i pandemija bolesti COVID-19}

Zdravstveni radnici pokazali su najveći rizik od štetnih psiholoških reakcija tijekom pandemije bolesti COVID-19, dok je izravni kontakt s infekcijom koronavirusom povezan sa značajnim porastom stresa među medicinskim osobljem (16). Medicinsko osoblje na prvoj liniji je pod povećanim psihološkim opterećenjem tijekom pandemije, s višim razinama stresa, anksioznosti i depresije od medicinskog osoblja druge linije (12). Međutim, osjećaj stigmatizacije nije izravno povezan s rizicima od infekcije i najzastupljeniji je među medicinskim sestrama i pomoćnim medicinskim osobljem (16). Meta-analiza Batre i suradnika iz 2020. godine, koja je obuhvatila 65 studija i ukupan uzorak od 79.437 sudionika, pokazala je prevalenciju anksioznosti od 34,4\%, depresije 31,8\%, stresa $40,3 \%$, posttraumatskog sindroma stresa $11,4 \%$, nesanice $27,8 \%$, psihološkog stresa 46,1\% i izgaranja 37,4\%. Analiza podskupina pokazala je veću prevalenciju anksioznosti i depresije među ženama, medicinskim sestrama i osobama na prvoj liniji borbe protiv pandemije, za razliku od nižih prevalencija u muškaraca, liječnika i zdravstvenih radnika na drugoj liniji (17).

Razine stresa pri suočavanju s biološkom prijetnjom kao što je COVID-19 u zdravstvenih radnika, potencijalno mogu izazvati i posttraumatski stresni sindrom, kao i povećati stopu psihosomatskih bolesti $(18,19)$. Osim psihičkih simptoma, medicinski radnici na prvoj liniji imaju veći rizik od zaraze virusima i iznenadne smrti i poremećaja povezanih s prekomjernim radom, uključujući kardiovaskularne bolesti (20).

Uz povećane stope rizika i više vrijednosti u Maslach upitniku o sindromu sagorijevanja, emocionalno iscrpljenje i depersonalizacija pozitivno koreliraju s dobi, spolom, zanimanjem, bračnim statusom, duljinom staža u struci te stupnjem obrazovanja. Varijable dobi
( $<29$ godina), zanimanje (medicinske sestre), bračni status (nevjenčani), godine staža u struci ( $<5$ godina), niži stupanj obrazovanja bili su povezani s višom razinom (21). Još neka istraživanja govore u prilog kako pandemija ugrožava psihološku dobrobit najmlađih i visokokvalificiranih stručnjaka (16).

Medscapeovo istraživanje iz 2021. godine o sindromu sagorijevanja i stopi suicida liječnika tijekom pandemije bolesti COVID-19, koje je obuhvatilo 12.338 ispitanika različitih specijalizacija, pokazalo je kako je $42 \%$ ispitanika u sindromu sagorijevanja, od čega je $79 \%$ navelo da je bilo u burnoutu i prije pandemije bolesti COVID-19, dok je 14\% liječnika imalo misli o samoubojstvu. Više je žena nego muškaraca izloženo burnoutu (51\% naspram 36\%). Od 29 različitih specijalnosti, najugroženiji su liječnici koji rade u jedinicama intenzivnog liječenja, infektolozi i reumatolozi. Ukupno 20\% liječnika zadovoljava kriterije za dijagnozu kliničke depresije.

Čimbenici koji su tome pridonijeli su nedostatak zaštitne opreme, teški uvjeti rada, zahtjevno radno vrijeme, žalovanje zbog preminulih pacijenta i promatranje patnje obitelji pacijenata. U usporedbi s Medscapeovim istraživanjem provedenim 2016. godine, vodeći razlozi nisu se puno promijenili - previše birokratskih poslova, previše sati rada, manjak poštovanja i nedovoljna kompenzacija rada.

U studiji iz 2021., kao česti načini na koji se liječnici nose sa sindrom sagorijevanja izdvojene su tjelovježba, razgovor s bliskim osobama, izolacija, spavanje, slušanje glazbe i konzumacija brze hrane i alkohola (13).

U 2020. godini, u Sjedinjenim Američkim Državama 54\% medicinskih sestara i tehničara bilo je u burnoutu (22). Medicinske sestre su izložene psihosocijalnim rizicima koji mogu narušavati i psihičko i somatsko zdravlje zbog stresnih uvjeta, a upravo prolongirani stres može dovesti do sindroma sagorijevanja (23). Među medicinskim sestrama gratifikacija empatijom, kao i iscrpljenost $\mathrm{u}$ empatiji i sindrom sagorijevanja imaju visoke stope, a negativno su povezani sa stupnjem ostvarenog obrazovanja me- 
dicinske sestre (24). Zbog toga je vrlo važan protektivni čimbenik psihosocijalnih rizika emocionalna inteligencija, koja se povezuje s psihičkim i fizičkim zdravljem, zadovoljstvom poslom, povećanom odgovornosti na poslu i smanjenjem stope burnouta (23). Također, u pregledom radu iz 2020. godine s temom sindroma sagorijevanja u medicinskih sestara, kao prediktori izgaranja izdvojeni su veliko opterećenje, vrijednosna neskladnost, niska kontrola nad poslom, loša socijalna klima/manjak socijalne podrške i nedostatne nagrade za rad. Ostali čimbenici koji su u literaturi klasificirani kao prediktori sagorijevanja bili su nizak/neadekvatan broj medicinskih sestara, $\geq 12$-satna smjena, mala fleksibilnost rasporeda, vremenski pritisak, visoki radni i psihološki zahtjevi, mala raznolikost zadataka, sukob uloga, niska autonomija, negativan odnos medicinske sestre i liječnika, loša podrška voditelja službe, loše vodstvo, negativan timski odnos i nesigurnost posla (24). U istraživanju koje je proučavalo, inače zanemarene, čimbenike koji pridonose sindromu sagorijevanja u medicinskih sestara, izdvojeni su nedovoljno priznanje važnosti zadataka koje medicinske sestre obavljaju, stereotipi o ženama i prekomjerna birokracija (25). Kao ozbiljne posljedice sagorijevanja identificirana je smanjena kvaliteta izvedbe posla, lošija kvaliteta zdravstvene njege, smanjena sigurnost pacijenta, veći rizik od štetnih događaja, negativno iskustvo pacijenta, pogreške u liječenju, infekcije i namjera da osoba napusti radno mjesto (24). Obrasci identificirani ovim studijama dosljedno pokazuju da su nepovoljne karakteristike posla - veliko opterećenje, nedovoljan broj osoblja, duge smjene i nizak stupanj kontrole - povezane sa sindrom izgaranja u medicinskih sestara.

\section{Kako smanjiti posljedice sindroma sagorijevanja?}

Potencijalne posljedice sindroma sagorijevanja za osoblje i pacijente su ozbiljne. Kao faktor na koji se može utjecati kako bi se smanjila stopa sindroma sagorijevanja zdravstvenog osoblja, ističe se organizacija posla, budući da se pokazalo kako burnout više ovisi o okolnostima radnog mjesta, nego o strukturi ličnosti (26). Dobra organizacija posla, rotacija osoblja, aktivno slušanje osobe te pošteda od teških zadataka ako je potrebno, mogla bi pridonijeti da do sindroma sagorijevanja niti ne dođe (27-29). Isto tako, profesionalna samoefikasnost izdvojena je kao učinkovit mehanizam suočavanja sa stresom izazvanim nepovoljnim radnim uvjetima, pa bi organizacije trebale pružiti medicinskim sestrama mogućnosti izrade strategije suočavanja sa stresom za upravljanje zahtjevima posla i teškim međuljudskim interakcijama (30).

Strategije nošenja sa stresom su moderirajući čimbenici koji mogu oporaviti gratifikaciju suosjećanja među medicinskim sestrama koje rade u jedinicama intenzivne skrbi (31). Ova studija naglašava potrebu za dizajniranjem ciljanih intervencije na nacionalnoj razini za jačanje otpornosti i poticanje posttraumatskog rasta medicinskih sestara i liječnika, posebice onih na prvoj liniji. Primjer dobre prakse mogu biti Sjedinjene Države koje su 2020. godine usvojile "Zakon o zaštiti pružatelja zdravstvenih usluga dr. Lorna Breen" (engl. Lorna Breen Health Care Provider Protection Act). Ovim se prijedlogom zakona od Ministarstva zdravstva i socijalnih usluga (HHS) zahtijeva poduzimanje potrebnih mjera za poboljšanje mentalnog zdravlja i sprječavanje sindroma izgaranja među pružateljima zdravstvenih usluga. HHS mora dodijeliti bespovratna sredstva školama za zdravstvena zanimanja, državnim ili lokalnim vlastima ili neprofitnim organizacijama, kako bi pružio obuku pružateljima zdravstvenih usluga o prevenciji samoubojstava, drugim pitanjima zdravstvenog ponašanja i strategijama, dajući prednost onima koji rade izravno s oboljelim od bolesti COVID-19, da uspostave ili prošire programe za promicanje mentalnog zdravlja među pružateljima zdravstvenih usluga koji su uključeni u napore na COVID-19. Nadalje, HHS također treba proučiti pitanja koja se odnose na burnout i razviti političke preporuke o sprječavanju sagorijevanja i poboljšanju mentalnog i bihevioralnog zdravlja među pružateljima zdravstvenih usluga, uklanjanju prepreka pristupu skrbi i liječenju, kao i utvrđivanju strategija za promicanje otpornosti na stres. Uz to, Centri za kontrolu i prevenciju bolesti (engl. CDC) moraju provesti kampanju kojom će potaknuti pružatelje zdravstvenih usluga da potraže podršku i liječenje zbog mentalnih i bihevioralnih zdravstvenih problema (32).

Za sindrom sagorijevanja poznato je da je u velikoj mjeri prisutan među zdravstvenim radnicima, a mogućnost za njegovu pojavu povećao je dodatni stres u poslu izazvanim pandemijom bolesti COVID-19. Brojke koje govore o velikom postotku zdravstvenih radnika zahvaćenih burnout sindromom pozivaju na žurnost u primjeni mjera prevencija, kao i kvalitetnih terapijskih pristupa za liječenje sindroma sagorijevanja u medicinskih sestara i liječnika. Postoji niz čimbenika koji djeluju protektivno u smislu razvoja i podržavanja otpornosti (engl. resilience), kao i niz čimbenika koji djeluju disruptivno na psihičko i tjelesno funkcioniranje. Otpornost i zdravi mehanizmi suočavanja sa stresom imaju protektivnu ulogu, ublažavaju posljedica stresa, kao i razinu traumatizacije stresnim događajima (33). Zbog toga je najpogodniji način za prevenciju sindroma sagorijevanja stavljanje fokusa na razvijanje pozitivnih psiholoških karakteristika osobe za nošenje sa stresom te modifikacija poslovnog okruženja $\mathrm{u}$ smjeru boljih uvjeta rada, a ne zasebni rad na jednom čimbeniku $(4,34)$. U istraživanjima se pokazalo kako je većina zdravstvenih radnika u burnout $\mathrm{u}$ otporu prema programima koje nudi njihova institucija za liječenje i prevenciju sindroma sagorijevanja, jer se često fokusiraju na trenutno olakšanje određenog simptoma, a ne raščlanjuju temeljne faktore, posebice na osobnoj razini i razini organizacije koji su doveli do distresa (13). Zdravstvene radnike kojima je značajno narušeno mentalno zdravlje zbog sindroma sagorijevanja, potrebno je uputiti na rehabilitaciju s ciljem oporavka radne i profesionalne sposobnosti. Glavna svrha liječenja u rehabilitaciji sindroma sagorijevanja prekidanje je začaranog kruga gubitka nečijih resursa što dovodi do još većeg izgaranja (34). Potrebna je strategija na nacionalnoj razini koja će služiti podršci, motivaciji, zaštiti i edukaciji zdravstvenih radnika o ovim bitnim pitanjima, čemu mogu služiti primjeri do- 
bre prakse iz drugih zemalja (npr. SAD), koje su prepoznale važnost u sprječavanju i liječenju sindroma sagorijevanja.

Prikupljeni podaci potvrđuju kako je od velikog značenja pravovremeno razviti strategije prevencije, liječenja i rehabilitacije osoba sa sindromom sagorijevanja, čime bi se održalo mentalno zdravlje medicinskog osoblja, ali i kvaliteta skrbi koja se pruža pacijentima unutar zdravstvenog sustava.

\section{NOVČANA POTPORA/FUNDING Nema/None}

\section{ETIČKO ODOBRENJE/ETHICAL APPROVAL Nije potrebno/None}

\section{SUKOB INTERESA/CONFLICT OF INTEREST}

Autori su popunili the Unified Competing Interest form na www.icmje.org/coi_disclosure.pdf (dostupno na zahtjev) obrazac i izjavljuju: nemaju potporu niti jedne organizacije za objavljeni rad; nemaju financijsku potporu niti jedne organizacije koja bi mogla imati interes za objavu ovog rada u posljednje 3 godine; nemaju drugih veza ili aktivnosti koje bi mogle utjecati na objavljeni rad./ All authors have completed the Unified Competing Interest form at www.icmje.org/coi disclosure. $p d f$ (available on request from the corresponding author) and declare: no support from any organization for the submitted work; no financial relationships with any organizations that might have an interest in the submitted work in the previous 3 years; no other relationships or activities that could appear to have influenced the submitted work.

\section{LITERATURA}

1. Freudenberger HJ. Staff Burn-Out. Journal of Social Issues. 1974; 30 (1).

2. Schaufeli WB, Maslach C, Leiter MP, Jackson SE. Maslach Burnout Inventory - General Survey (MBI-GS). MBI Manual. 1996; (January).

3. Maslach C. Burned-out. Human Behavior. 1976; 9: 16-22.

4. Kakiashvili T, Leszek J, Rutkowski K. The medical perspective on burnout. International Journal of Occupational Medicine and Environmental Health. 2013; 26 (3).

5. Schaufeli WB, Leiter MP, Maslach C. Burnout: 35 years of research and practice. Vol. 14, Career Development International. 2009.

6. Ajduković M, Ajduković D. Pomoć i samopomoć u skrbi za mentalno zdravlje pomagača. Zagreb: Društvo za psihološku pomoć; 1994.

7. Huang L, Zhang Y, Yao YC, Cui FF, Shi T, Wang YW, et al. (Effects of Personality and Psychological Acceptance on Medical Workers' Occupational Stress). Chinese Journal of Industrial Hygiene and Occupational Diseases. 2018; 36 (7).
8. Polyakova OB, Bonkalo TI. Features of psychosomatization of medical professionals with occupational deformations. Health Care of the Russian Federation. 2021; 64 (5).

9. Waddill-Goad SM. Stress, Fatigue, and Burnout in Nursing. Journal of Radiology Nursing. 2019 Mar; 38 (1).

10. Rotenstein LS, Torre M, Ramos MA, Rosales RC, Guille C, Sen S, et al. Prevalence of burnout among physicians a systematic review. Vol. 320, JAMA - Journal of the American Medical Association. 2018.

11. Vizheh M, Qorbani M, Arzaghi SM, Muhidin S, Javanmard Z, Esmaeili M. The mental health of healthcare workers in the COVID-19 pandemic: A systematic review. Vol. 19, Journal of Diabetes and Metabolic Disorders. 2020.

12. Antonijevic J, Binic I, Zikic O, Manojlovic S, Tosic-Golubovic S, Popovic N. Mental health of medical personnel during the COVID-19 pandemic. Brain and Behavior. 2020; 10 (12).

13. Leslie Kane M. "Death by 1000 Cuts": Medscape National Physician Burnout \& Suicide Report 2021. https://www.medscape.com/ slideshow/2021-lifestyle-burnout-6013456. 2021.

14. Stehman CR, Testo Z, Gershaw RS, Kellogg AR. Burnout, drop out, suicide: Physician loss in emergency medicine, part I. Vol. 20, Western Journal of Emergency Medicine. 2019.

15. Chirico F, Magnavita N. Burnout syndrome and meta-analyses: Need for evidence-based research in occupational health. comments on prevalence of burnout in medical and surgical residents: A meta-analysis. int. j. environ. res. public. health. 2019, 16, doi:10.3390/ ijerph16091479. International Journal of Environmental Research and Public Health. 2020; 17 (3): 7-8.

16. Sorokin MY, Kasyanov ED, Rukavishnikov G v., Makarevich O v., Neznanov NG, Morozov $\mathrm{P}$ v., et al. Stress and stigmatization in healthcare workers during the COVID-19 pandemic. Indian Journal of Psychiatry. 2020; 62 (9).

17. Batra K, Singh TP, Sharma M, Batra R, Schvaneveldt $N$. Investigating the psychological impact of COVID-19 among healthcare workers: A meta-analysis. International Journal of Environmental Research and Public Health. 2020; 17 (23).

18. Asaoka H, Koido Y, Kawashima Y, Ikeda M, Miyamoto Y, Nishi D. Post-traumatic stress symptoms among medical rescue workers exposed to COVID-19 in Japan. Vol. 74, Psychiatry and Clinical Neurosciences. 2020.

19. Yi J, Kang L, Li J, Gu J. A Key Factor for Psychosomatic Burden of Frontline Medical Staff: Occupational Pressure During the COVID-19 Pandemic in China. Frontiers in Psychiatry. 2021; 11.

20. Zhang F, Wang $\mathrm{H}$, Chen $\mathrm{R}$, Hu W, Zhong Y, Wang $\mathrm{X}$. Remote monitoring contributes to preventing overwork-related events in health workers on the COVID-19 frontlines. Precision Clinical Medicine. 2020; 3 (2).
21. Wang J, Hu B, Peng Z, Song H, Cai S, Rao X, et al. Prevalence of burnout among intensivists in mainland China: a nationwide cross-sectional survey. Critical Care. 2021; 25 (1): 1-10.

22. Kelly LA, Gee PM, Butler RJ. Impact of nurse burnout on organizational and position turnover. Nursing Outlook. 2021; 69 (1).

23. Soto-Rubio A, Giménez-Espert MDC, PradoGascó V. Effect of emotional intelligence and psychosocial risks on burnout, job satisfaction, and nurses' health during the covid-19 pandemic. International Journal of Environmental Research and Public Health. 2020; 17 (21).

24. Dall'Ora C, Ball J, Reinius M, Griffiths P. Burnout in nursing: a theoretical review. Human Resources for Health. 2020 Dec 5; 18 (1).

25. Manzano-García G, Ayala J-C. Insufficiently studied factors related to burnout in nursing: Results from an e-Delphi study. PLOS ONE. 2017 Apr 7; 12 (4).

26. Nogueira L de S, Sousa RMC de, Guedes E de S, Santos MA dos, Turrini RNT, Cruz D de ALM da. Burnout and nursing work environment in public health institutions. Revista Brasileira de Enfermagem. 2018 Apr; 71 (2).

27. Gemine R, Davies GR, Tarrant S, Davies RM, James M, Lewis K. Factors associated with work-related burnout in NHS staff during COVID-19: A cross-sectional mixed methods study. BMJ Open. 2021; 11 (1).

28. Kärkkäinen R, Saaranen T, Hiltunen S, Ryynänen OP, Räsänen K. Systematic review: Factors associated with return to work in burnout. Occupational Medicine. 2017; 67 (6).

29. Bragard I, Hansez I, Coucke P. Working conditions, job strain and work engagement among Belgian radiation oncologists. Cancer/Radiotherapie. 2014; 18 (8).

30. Fida R, Laschinger HKS, Leiter MP. The protective role of self-efficacy against workplace incivility and burnout in nursing. Health Care Management Review. 2018 Jan; 43 (1).

31. al Barmawi MA, Subih M, Salameh O, Sayyah Yousef Sayyah N, Shoqirat N, Abdel-Azeez Eid Abu Jebbeh R. Coping strategies as moderating factors to compassion fatigue among critical care nurses. Brain and Behavior. 2019; 9 (4).

32. Kaine T. Dr. Lorna Breen Health Care Provider Protection Act. 2020.

33. Maiorano T, Vagni M, Giostra V, Pajardi D. COVID-19: Risk factors and protective role of resilience and coping strategies for emergency stress and secondary trauma in medical staff and emergency workers - an online-based inquiry. Sustainability (Switzerland). 2020; 12 (21).

34. Hätinen M, Kinnunen U, Pekkonen M, Kalimo R. Comparing Two Burnout Interventions: Perceived Job Control Mediates Decreases in Burnout. International Journal of Stress Management. 2007; 14 (3). 


\title{
Summary \\ BURNOUT SYNDROME IN HEALTH PROFESSIONALS DURING THE COVID-19 PANDEMIC
}

\author{
Stipe Drmić, Lea Murn
}

Burnout syndrome is a result of chronic stress at work, with the use of relatively ineffective coping strategies, and numerous studies conducted on nurses and physicians confirm that health professionals are particularly exposed to it. During the pandemic of COVID-19, medical staff has been exposed to additional stressors, which increase the possibility of developing burnout syndrome. This review paper provides recent data on the prevalence rate of burnout syndrome in healthcare professionals (nurses and physicians), before and during the SARS-CoV-19 virus crisis, and discusses the factors influencing the development of burnout syndrome, in order to identify the factors protecting the mental health of health professionals. The data collected in numerous studies confirm the importance of timely development of strategies for prevention, treatment, and rehabilitation of persons with burnout, which would maintain the mental health of medical staff, but also the quality of care provided to patients within the health system.

Key words: BURNOUT SYNDROME, COVID-19, NURSES, PHYSICIANS

Primljeno/Received: 26. 3. 2021

Prihvaćeno/Accepted: 22. 4. 2021. 